\title{
Benzocaine-induced methemoglobinemia: A condition of which all endoscopists should be aware
}

\author{
C Armstrong BSc, KW Burak MD FRCPC, PL Beck MD PhD FRCPC
}

C Armstrong, KW Burak, PL Beck. Benzocaine-induced methemoglobinemia: A condition of which all endoscopists should be aware. Can J Gastroenterol 2004;18(10):625-629.

Methemoglobinemia is a rare complication that can occur with the use of benzocaine-containing compounds. Two cases of methemoglobinemia are reported, and the pathophysiology and treatment of methemoglobinemia are reviewed. Both patients received topical $20 \%$ benzocaine spray before endoscopy. Immediately following the procedure, there was a reduction in $\mathrm{O}_{2}$ saturation assessed by pulse oximetry that was refractory to $\mathrm{O}_{2}$ therapy. Dramatic peripheral and central cyanosis developed. $\mathrm{O}_{2}$ saturation measured by pulse oximetry ranged from $83 \%$ to $87 \%$ on $\mathrm{O}_{2}$ by nasal prongs and $100 \% \mathrm{O}_{2}$ by a nonrebreathing mask. Both patients were mildly confused and one patient complained of a significant headache. The diagnosis of methemoglobinemia was considered and arterial blood gas sampling was performed. In both patients, the arterial blood had a chocolate brown colour. A methemoglobin level of $48 \%$ and $18 \%$ was noted in patient 1 and patient 2, respectively. Both patients were treated with methylene blue, resulting in a significant improvement with gradual normalization of their $\mathrm{O}_{2}$ saturation within $10 \mathrm{~min}$ to $30 \mathrm{~min}$. The use of benzocaine spray may not markedly alter the patient's perception of endoscopy and thus, the routine use of these agents should be questioned. If such agents are used, the physician must be aware of this association to prevent a delay in the diagnosis and management of this rare, but potentially lethal, condition.

Key Words: Benzocaine spray; Methemoglobinemia; Upper endoscopy

$\mathrm{M}$ ethemoglobinemia is a serious and potentially fatal complication that can occur with the use of benzocainecontaining anesthetics and a wide variety of other pharmacological agents. Due to the routine use of benzocaine as a topical anesthetic during endoscopy, all endoscopists should be aware of this reaction. Methemoglobinemia arises when an exogenous substance, such as benzocaine, oxidizes the iron moiety of hemoglobin from a ferrous to a ferric state, forming methemoglobin $(\mathrm{MHg})$ at a rate 100 to 1000 times faster than it can be metabolized. $\mathrm{MHg}$ can no longer bind $\mathrm{O}_{2}$ properly, resulting in a shift of the $\mathrm{O}_{2}$ dissociation curve to the left, thereby compromising the transport of $\mathrm{O}_{2}$ from the lungs to metabolically active tissue. Patients typically present with peripheral cyanosis, mildly low $\mathrm{O}_{2}$ saturation levels by pulse oximetry and chocolate brown-coloured arterial blood. Benzocaine is typically given as a topical anesthetic during endoscopy and is administered by spraying the oral pharynx. We describe two cases of significant symptomatic methemoglobinemia occurring in the endoscopic unit at the Foothills Medical Center (Calgary, Alberta) in a

\author{
La méthémoglobinémie induite par la \\ benzocaïne : Un trouble que tous les \\ endoscopistes devraient connaître
}

La méthémoglobinémie est une complication rare qui peut surgir par suite de l'usage de composés contenant de la benzocaïne. On rend compte de deux cas de méthémoglobinémie, et on examine la physiopathologie et le traitement de la méthémoglobinémie. Les deux patients ont reçu une vaporisation topique de benzocaïne $20 \%$ avant l'endoscopie. Tout de suite après l'intervention, on a remarqué une réduction de la saturation en $\mathrm{O}_{2}$ évaluée par une oxymétrie réfractaire à l'oxygénothérapie. Une cyanose centrale et périphérique spectaculaire s'est manifestée. La saturation en oxygène mesurée d'après l'oxymétrie pulsée oscillait entre $83 \%$ et $87 \%$ avec les pinces nasales et s'élevait à $100 \%$ avec le masque sans réinspiration. Les deux patients étaient légèrement confus, et l'un s'est plaint de gros maux de tête. Le diagnostic de méthémoglobinémie a été envisagé, et une gazométrie du sang artériel a été effectuée. Chez les deux patients, le sang artériel était brun chocolat. Un taux de méthémoglobine de $48 \%$ et de $18 \%$ a été relevé chez le premier et le deuxième patient, respectivement. Les deux patients ont été traités au bleu de méthylène, ce qui a suscité une amélioration considérable et une normalisation graduelle de leur saturation en $\mathrm{O}_{2}$ dans les 10 à 30 minutes. L'utilisation d'une vaporisation de benzocaïne ne modifie peut-être pas sensiblement la perception que le patient a de l'endoscopie. C'est pourquoi l'utilisation systématique de cet agent devrait être remise en question. S'il est utilisé, le médecin devrait être conscient de cette association afin de prévenir un délai dans le diagnostic et la prise en charge de ce trouble rare, au potentiel pourtant fatal.

two-month period. A further review of the diagnosis, treatment and pathophysiology of this condition is warranted given the common use of benzocaine-containing agents during endoscopy, and because many gastroenterologists, gastroenterology fellows and residents are unaware of this adverse drug reaction.

\section{CASE PRESENTATIONS}

Case 1

A 60-year-old woman who had a cardiac transplant for cardiomyopathy three years ago was undergoing an upper endoscopy for investigation of microcytic anemia. Her past medical history was significant for lupus erythematosus and chronic renal insufficiency (creatinine $212 \mu \mathrm{mol} / \mathrm{L}$ ). Her medications included cyclosporine, mycophenolate mofetil, omeprazole, enalapril maleate, pravastatin sodium, diltiazem hydrochloride, epoetin alfa and etidronate sodium. The patient also routinely took $1 \mathrm{~g}$ of vitamin $\mathrm{C}$ per day. All of these medications were last taken the day before the endoscopy.

Division of Gastroenterology, University of Calgary, Calgary, Alberta

Correspondence: Dr Paul L Beck, University of Calgary, Health Sciences Centre, Division of Gastroenterology, 3330 Hospital Drive Northwest,

Calgary, Alberta T2N 4N1. Telephone 403-220-4500, fax 403-270-0995, e-mail plbeck@ucalgary.ca

Received for publication December 1, 2003. Accepted July 8, 2004 
The patient was sedated with a total of $4 \mathrm{mg}$ of midazolam and $50 \mu \mathrm{g}$ fentanyl. Her oropharynx was sprayed twice with the benzocaine-containing topical anesthetic (Hurricane spray; Beutlich Pharmaceuticals, USA). The endoscope was inserted into the esophagus and the stomach was examined without difficulty. A slight reduction in $\mathrm{O}_{2}$ saturation was noted approximately 15 min following the administration of the topical anesthetic, with a drop in $\mathrm{O}_{2}$ saturation from $95 \%$ to $97 \%$ to $88 \%$ to $90 \%$. The patient was started on $4 \mathrm{~L} / \mathrm{min}$ of $\mathrm{O}_{2}$ by nasal prongs and was transferred to the recovery room. Her $\mathrm{O}_{2}$ saturation dropped to $84 \%$ to $86 \%$ and the nursing staff increased the $\mathrm{O}_{2}$ in a step-wise fashion until she was placed on a $100 \% \mathrm{O}_{2}$ nonrebreathing mask. There was no significant improvement in $\mathrm{O}_{2}$ saturation. The physician was then alerted to the patient's deterioration.

The patient was found to have profound peripheral and central cyanosis. Her cardiac and respiratory exams were normal. Her blood pressure was $107 / 73 \mathrm{mmHg}$, heart rate was 96 beats/min and $\mathrm{O}_{2}$ saturation by pulse oximetry was $82 \%$ to $89 \%$ on $100 \% \mathrm{O}_{2}$ by a nonrebreathing mask. Her chest and cardiovascular exam were normal but she was dyspneic, drowsy and confused. Flumazenil ( $0.2 \mathrm{mg}$ intravenously) and naloxone hydrochloride ( $0.4 \mathrm{mg}$ intravenously) were administered without a significant response. The $\mathrm{O}_{2}$ was briefly discontinued without a significant change in her $\mathrm{O}_{2}$ saturation or clinical condition. The patient denied any chest pain or shortness of breath, but did have a significant headache and stated she felt generally unwell. Her chest $\mathrm{x}$-ray and electrocardiogram were unremarkable.

With no change in her $\mathrm{O}_{2}$ saturation with or without $\mathrm{O}_{2}$, as well as the significant peripheral and central cyanosis, the diagnosis of methemoglobinemia was considered. An arterial blood gas was requested. The arterial blood was chocolate brown coloured which further suggested the diagnosis of methemoglobinemia. Methylene blue was ordered as the blood gas was processed. Methemoglobinemia was confirmed with arterial blood gas analysis with an $\mathrm{MHg}$ level of $48.7 \%$ (normal $0.0 \%$ to $1.5 \%)$. The patient was treated with $1.5 \mathrm{mg} / \mathrm{kg}$ of methylene blue given intravenously as an intravenous push into an intravenous line with normal saline running at $200 \mathrm{~mL} / \mathrm{h}$ over a period of $5 \mathrm{~min}$. Within $5 \mathrm{~min}$ of methylene blue administration, the patient started feeling better and her colour improved. Her headache resolved over approximately $30 \mathrm{~min}$ to $45 \mathrm{~min}$.

Following methylene blue administration, her $\mathrm{O}_{2}$ saturation by pulse oximetry fell further to approximately $65 \%$, indicating that the methylene blue likely interfered with the ability of pulse oximetry to accurately assess $\mathrm{O}_{2}$ saturation. In addition, within a few minutes of its administration, the patient experienced significant nausea and vomiting, a noted side effect of methylene blue treatment. This was successfully treated with ondansetron ( $4 \mathrm{mg}$ intravenously). The peripheral and central cyanosis completely resolved within $30 \mathrm{~min}$ of methylene blue administration. An arterial blood gas repeated $2 \mathrm{~h}$ later showed an $\mathrm{MHg}$ of $6.0 \%$. The patient was discharged $2 \mathrm{~h}$ later (approximately $5 \mathrm{~h}$ after the administration of methylene blue) in stable condition and feeling completely well. The patient refused a further in-hospital observation period but was closely observed at home by her spouse and directed to seek medical attention immediately if she developed further problems. Follow-up phone calls by her physician at $3 \mathrm{~h}$ and $12 \mathrm{~h}$ following discharge revealed that she was completely asymptomatic and felt well. Due to the mildly elevated $\mathrm{MHg}$ level, the patient was instructed to take $1 \mathrm{~g}$ of vitamin $\mathrm{C}$ twice a day for two days and then to continue with her usual dose of vitamin $C$. The patient had no further problems and was instructed to avoid benzocaine-containing compounds.

\section{Case 2}

A 22-year-old woman was admitted to hospital for investigation of persistent nausea, vomiting and weight loss of $7 \mathrm{~kg}$. She had undergone an appendectomy two months earlier but was otherwise healthy and was only taking antiemetics. An endoscopy performed one month earlier in a local hospital revealed gastritis and duodenitis. The day after admission she developed coffee ground hematemesis and a repeat gastroscopy was performed. Before the endoscopy, the patient received topical Hurricane spray to the oropharynx. The patient was sedated with $6 \mathrm{mg}$ of midazolam and $100 \mu \mathrm{g}$ fentanyl in incremental doses. The gastroscope was introduced into the esophagus without difficulty. A shallow, clean-based gastric ulcer was found in the antrum but the endoscopy was otherwise unremarkable. During the procedure, the $\mathrm{O}_{2}$ saturation was noted to be $88 \% . \mathrm{O}_{2}$ was administered at a rate of $4 \mathrm{~L} / \mathrm{min}$ by nasal prongs. She was transferred to the inpatient ward in stable condition; however, her $\mathrm{O}_{2}$ saturation remained in the $85 \%$ to $88 \%$ range. $\mathrm{O}_{2}$ was administered with a nonrebreathing mask but her $\mathrm{O}_{2}$ saturation remained lower than $88 \%$. She was alert and oriented, and complained of mild dyspnea. Her chest exam was normal and her chest $\mathrm{x}$-ray was also unremarkable. Arterial blood gas analysis revealed an $\mathrm{MHg}$ level of $18.8 \%$ (normal $0.0 \%$ to $1.5 \%$ ). A total of $50 \mathrm{mg}$ (approximately $1 \mathrm{mg} / \mathrm{kg}$ ) of methylene blue was administered by direct intravenous push over $5 \mathrm{~min}$. Repeat blood gases $90 \mathrm{~min}$ later showed resolution of the methemoglobinemia ( $\mathrm{MHg} \mathrm{1.2 \% ),}$ and she was completely asymptomatic. She was transferred back to the medical ward $3.5 \mathrm{~h}$ following the administration of methylene blue and her vital signs were monitored closely. Further investigations into her nausea and vomiting were completed and were unrevealing. Her nausea and vomiting spontaneously improved and she was discharged after one week in hospital with instructions to avoid benzocaine-containing compounds in the future.

\section{DISCUSSION}

Benzocaine has been associated with methemoglobinemia in a wide variety of different preparations and concentrations ( $5 \%$ to $20 \%$ ), including over-the-counter preparations used for the relief of pain and itching associated with vaginal irritation (1), oral sores (2) and in its use as a topical anesthetic spray during intubation, bronchoscopy, transesophogeal electrocardiography and endoscopy (3-12). MHg is formed when an iron moiety of hemoglobin is oxidized from a ferrous ion to a ferric ion $\left(\mathrm{Fe}^{3+}\right)$. MHg has an impaired $\mathrm{O}_{2}$ binding capacity and is unable to carry $\mathrm{O}_{2}$ from the lungs to metabolically active tissue. Furthermore, the oxidation of one subunit of the hemoglobin tetramer to $\mathrm{MHg}$ prevents the remaining normal subunits from unloading their bound $\mathrm{O}_{2}$, causing an additional leftward shift in the $\mathrm{O}_{2}$ dissociation curve. In the case of benzocaine, a toxic metabolite $\mathrm{N}$-hydroxy derivative is thought to be responsible for the oxidation of hemoglobin to $\mathrm{MHg}$ (13). Under normal physiological conditions, approximately $0.5 \%$ of total hemoglobin exists in the oxidized form of $\mathrm{MHg}$ (14). These low levels of $\mathrm{MHg}$ are predominantly maintained 
enzymatically by NADH-MHg reductase; which is a twoenzyme system involving both cytochrome- $b_{5}$ and cytochrome- $b_{5}$ reductase; the latter reduces methemoglobin back to its functional form (15) (Figure 1). Another important enzyme involved in reducing $\mathrm{MHg}$ is NADPH-MHg reductase. The activity of this enzyme to reduce $\mathrm{MHg}$ is greatly increased by methylene blue (Figure 1) (16). Other agents, such as ascorbic acid and glutathione, can act indirectly in these pathways to reduce oxidative stress and may thus prevent further production of $\mathrm{MHg}$ (17).

Methemoglobinemia arises when the level of $\mathrm{MHg}$ rises above 5\% (Figure 1). Individuals that are deficient in the amount of NADH-MHg reductase (autosomal recessive deficiencies in cytochrome- $b_{5}$ or cytochrome- $b_{5}$ reductase) have congenital methemoglobinemia. The congenital form of methemoglobinemia is most common in Alaskan Native Americans and individuals of Inuit descent (18-20). MHg levels in individuals with this congenital form of methemoglobinemia are usually between $15 \%$ and $30 \%$ of total hemoglobin, and individuals are normally asymptomatic except for varying degrees of persistent cyanosis. Another form of congenital methemoglobinemia occurs in individuals who display an aberrant form of hemoglobin $(\mathrm{HbM})$, where the reduced ferrous ion is destabilized and is more easily oxidized to a ferric ion. In addition, the enzyme methemoglobin reductase cannot interact with and efficiently reduce the $\mathrm{MHg}$ in individuals displaying this form of hemoglobin (21).

Acquired methemoglobinemia occurs when an exogenous substance, typically a pharmacological agent, oxidizes hemoglobin producing $\mathrm{MHg}$ at rates 100 to 1000 times greater than it can be metabolized (Figure 1). Methemoglobinemia has been observed with a wide variety of different compounds including lidocaine, procaine, antimalarials, dapsone, nitrate derivatives such as nitroglycerin, nitrofuran, nitric oxide and nitroprusside, and numerous other compounds $(16,17,22)$. Of particular importance to the endoscopist is the occurrence of methemoglobinemia with benzocaine-containing topical anesthetics. The incidence of benzocaine-induced methemoglobinemia in bronchoscopy is estimated to be one in 7000 exposures (16) and is most common in pediatric and elderly patients $(23,24)$. Small infants are at increased risk because they have markedly lower levels of cytochrome- $b_{5}$ reductase (25) and fetal hemoglobin is more easily oxidized to $\mathrm{MHg}$ (17). The activity of some enzymes involved in these processes is less efficient in the elderly $(13,17)$. Methemoglobinemia has also been reported in dialysis patients and may be a result of chloramine toxicity due to inadequate removal by hemodialysis filters (26).

Patients with methemoglobinemia present with a wide spectrum of symptoms depending on the amount of MHg present in the blood. The initial symptoms of methemoglobinemia, such as visible cyanosis and chocolate brown-coloured arterial blood, typically begin to appear when the level of $\mathrm{MHg}$ rises above $10 \%$ to $15 \%$ and are unresponsive to $\mathrm{O}_{2}$ therapy (13). As the level of MHg rises past 20\%, patients may exhibit anxiety, fatigue, dyspnea, dizziness, tachycardia, headache and syncope (13). Stupor, coma and convulsions have been reported with $\mathrm{MHg}$ levels greater than $50 \%(13,23,24,27)$, and death from cardiac hypoxia has been reported when levels exceed $70 \%(17,22)$.

The diagnosis of methemoglobinemia is based on clinical and laboratory findings. The cyanosis is generally out of

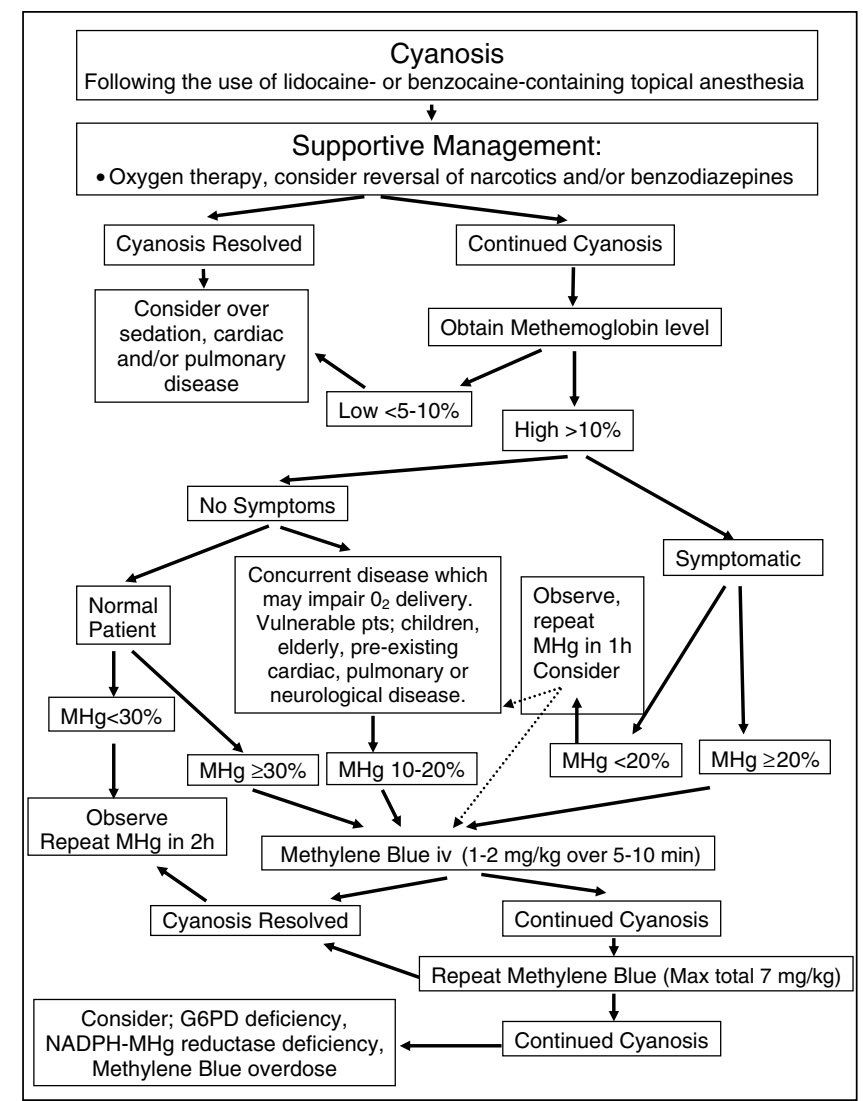

Figure 1) Clinical decision-making algorithm for methemoglobinemia induced by the use of lidocaine- or benzocaine-containing topical anesthetics during endoscopy. Adapted from Abdallah and Shah (3). G6PD Glucose-6-phosphate dehydrogenase; IV Intravenous; $\mathrm{MHg}$ Methemoglobin; pts Patients

proportion to the respiratory status of the individual and does not respond to $\mathrm{O}_{2}$ therapy. This was clearly seen in both patients, where high-flow $\mathrm{O}_{2}$ did not alter the cyanosis nor did cessation of supplemental $\mathrm{O}_{2}$. The other classic clinical finding is chocolate brown arterial blood, again seen in both patients. The blood fails to change colour when exposed to supplemental $\mathrm{O}_{2}$ or when a drop is placed on filter paper (13). This bedside maneuver is a quick and accurate test to differentiate cyanosis due to other causes than from $\mathrm{MHg}$ formation, because exposure of blood to a stream of $\mathrm{O}_{2}$ will turn the arterial blood bright red in cases of cyanosis not associated with methemoglobinemia. The determination of $\mathrm{O}_{2}$ saturation $\left(\mathrm{SpO}_{2}\right)$ by pulse oximetry is based on the fact that oxyhemoglobin absorbs more light at $940 \mathrm{~nm}$ and reduced hemoglobin absorbs more light at $660 \mathrm{~nm}$. Because $\mathrm{MHg}$ absorbs light equally at both these wavelengths, $\mathrm{SpO}_{2}$ by pulse oximetry can be misleading in these patients. Due to these alterations in normal light absorption, as $\mathrm{MHg}$ levels reach 30\% to 35\%, $\mathrm{SpO}_{2}$ measured by pulse oximetry becomes stable at $82 \%$ to $86 \%$ independent of the actual MHg level (17). Co-oximetry that measures light absorbance at four different wavelengths is an accurate method of determining $\mathrm{MHg}$ levels and is the method used in most hospital laboratories. Arterial blood gas analysis is also misleading in these patients. The way in which the partial pressure of $\mathrm{O}_{2}$ is calculated does not directly assess the number of $\mathrm{O}_{2}$ molecules bound to hemoglobin but 
measures the dissolved $\mathrm{O}_{2}$ in the sample and, thus, patients with life-threatening $\mathrm{MHg}$ can have normal or elevated $\mathrm{SpO}_{2}$ levels (17).

Methylene blue dramatically improves the efficiency of NADPH-MHg reductase and, thus, is an effective treatment for this condition. Methylene blue should be administered intravenously at a dose of $1 \mathrm{mg} / \mathrm{kg}$ to $2 \mathrm{mg} / \mathrm{kg}$ over a period of $5 \mathrm{~min}$ (16). Symptoms typically resolve within $30 \mathrm{~min}$ following its administration (28). Doses of methylene blue exceeding $7 \mathrm{mg} / \mathrm{kg}$ have been associated with severe hemolytic anemia (29). Furthermore, high concentrations of methylene blue can lead to $\mathrm{MHg}$ production by directly oxidizing hemoglobin to $\mathrm{MHg}$ (22). Because the enzyme responsible for the reduction of $\mathrm{MHg}$ during methylene blue therapy is NADPH-dependent, patients with glucose-6-phosphate dehydrogenase (G6PD) deficiencies should not be treated with methylene blue because this can result in severe hemolytic anemia. It has been suggested that low doses of methylene blue can be used in patients with G6PD deficiency, but in view of the likely inefficacy of this therapy in such individuals and the possible severe complications, most recommend treatment of these patients with ascorbic acid, exchange transfusions and hyperbaric $\mathrm{O}_{2}$ therapy (17).

G6PD deficiency is a common, X-linked condition that has been estimated to affect more than 200 million people throughout the world (30). There are over 400 variants of G6PD but the most common, clinically significant G6PD variant primarily affects individuals of central African decent and, thus, affects approximately $11 \%$ of African-descended males in the United States. A second, more severe variant is relatively common in those of Mediterranean descent; particularly, Sardinians and Sephardic Jews. A third, slightly less severe variant occurs in southern Chinese populations (30). The diagnosis of G6PD deficiency should be considered in any individual, particularly a male of African or Mediterranean descent, who experiences an acute hemolytic episode (30).

Generally, methylene blue should reduce MHg levels significantly in less than $1 \mathrm{~h}$ (17). If a patient with methemoglobinemia does not respond well to methylene blue therapy, it could be due to several different factors. Because the major source of NADH in red blood cells is derived from the catabolism of sugar via glycolysis, and dextrose is required for the formation of NADPH that is necessary for methylene blue to enhance $\mathrm{MHg}$ clearance, adequate amounts of dextrose should be available (17). If cyanosis does not initially respond to methylene blue, repeat doses can be given but should not exceed $5 \mathrm{mg} / \mathrm{kg}$ to $7 \mathrm{mg} / \mathrm{kg}$. Inefficacy of methylene blue therapy could also indicate G6PD or NADPH-MHg reductase deficiency and, thus, should be considered before methylene blue therapy. The age of the patient, their drug history and the presence of metabolic acidosis could also affect MHg clearance.

Previous reports have indicated that their patients were admitted to the intensive care unit and monitored for up to $24 \mathrm{~h}$ to $48 \mathrm{~h}(2,3,5,6,9)$. The present patients were managed on the postendoscopy recovery ward at the Foothills Medical Centre. The patients were monitored at all times during their recovery period. Following consultation with the hematology service and the intensive care unit, the patients were discharged from the recovery unit to the medical floor and monitored there (patient 2), while patient 1 refused hospitalization and was discharged $5 \mathrm{~h}$ following administration of methylene blue. Both patients were asymptomatic at the time of discharge from the recovery unit, $3.5 \mathrm{~h}$ (patient 2 ) and $5 \mathrm{~h}$ (patient 1 ) following methylene blue administration. A review of the literature on methemoglobinemia demonstrated that there were no cases in which an increase in MHg levels occurred following treatment. Pharmacology and physiology data suggest that there is a linear decline in $\mathrm{MHg}$ levels following treatment $(15,31)$. Increases in $\mathrm{MHg}$ levels could theoretically occur with preparations or agents that are slowly absorbed such as creams, ointments, slow release oral formulations or depot injections. Pharmacological studies (12) have shown that benzocaine sprays are rapidly absorbed. We suspect that numerous patients have had undiagnosed, mild increases in $\mathrm{MHg}$ levels following benzocaine exposure during endoscopy or bronchoscopy and have been sent home as would patients without methemoglobinemia. Clearly, a study measuring MHg levels in consecutive patients following endoscopy or bronchoscopy would shed more light on the actual prevalence of this benzocaine-induced side effect. All patients with methemoglobinemia should be closely monitored in hospital. Once they have responded to therapy and are asymptomatic, decisions on discharge or disposition should be made on a case-by-case basis with consultation with the intensive care unit and hematology.

The occurrence of methemoglobinemia appears to be idiosyncratic. It has been shown to occur both in healthy individuals and those with underlying illness. Furthermore, cases of methemoglobinemia have been reported in individuals with or without prior benzocaine exposure. The cases we have reported emphasize the fact that methemoglobinemia can occur in young, healthy adults on minimal medications and in those with complicated medical conditions. Some authors (13) suggest that differences in the absorption and metabolism of benzocaine-containing compounds could contribute to the occurrence of methemoglobinemia. Benzocaine should not be applied to lesions, inflamed or broken mucosa because this may increase the absorption of benzocaine. To minimize the absorption of these compounds, excess solution should be removed by having the patient expectorate and/or via suctioning (13). There was a large difference in the $\mathrm{MHg}$ levels observed in our two cases. Patient 1 had been taking ascorbic acid daily and discontinued it the day before endoscopy. It is unclear whether the abrupt discontinuation of ascorbic acid before endoscopy could have led to an altered redox state in this patient, thus contributing to the development of methemoglobinemia. Another factor that could possibly predispose patients to the development of methemoglobinemia is increasing age because methemoglobin reductase appears to be less efficient in elderly patients (24). Acidosis can also promote $\mathrm{MHg}$ formation and should be considered when using agents that can induce $\mathrm{MHg}$ formation.

If left undiagnosed and untreated, methemoglobinemia can be fatal. Many of the gastroenterologists and gastroenterology fellows informed of the present cases were unaware of this adverse reaction to benzocaine-containing compounds. We hope the presentation of these two cases and a review of methemoglobinemia literature will be of value to other endoscopists. There is literature $(32,33)$ suggesting that the use of benzocaine as a topical anesthetic does not alter the patient's perception of the procedure when combined with benzodiazepine sedation. Thus, we feel the routine use of these agents in endoscopy suite should be avoided. Furthermore, endoscopists should be aware of how to diagnose this condition, and methylene blue should be readily available in all endoscopy 
suites to ensure prompt treatment of this condition. The endoscopist should also be aware of the risk of using benzocainecontaining compounds and methylene blue in patients with G6PD deficiency.

ACKNOWLEDGEMENTS: Dr Beck is supported by the Alberta Heritage Foundation for Medical Research and Canadian Institutes of Health Research. Mr Armstrong was supported by an Alberta Heritage Foundation for Medical Research Summer Studentship.

\section{REFERENCES}

1. Currie JL, Mott LA, Pennisi SC, Smith BD, Smith RP. Potential for an external vaginal antiitch cream containing benzocaine to cause methemoglobinemia in healthy women. Am J Obstet Gynecol 1997;176:1006-8.

2. Gilman CS, Veser FH, Randall D. Methemoglobinemia from a topical oral anesthetic. Acad Emerg Med 1997;4:1011-3.

3. Abdallah HY, Shah SA. Methemoglobinemia induced by topical benzocaine: A warning for the endoscopist. Endoscopy 2002;34:730-4.

4. Maher P. Methemoglobinemia: An unusual complication of topical anesthesia. Gastroenterol Nurs 1998;21:173-5. Erratum in: 1998;21:224.

5. Lee E, Boorse R, Marcinczyk M. Methemoglobinemia secondary to benzocaine topical anesthetic. Surg Laparosc Endosc 1996;6:492-3.

6. Shua-Haim JR, Gross JS. Methemoglobinemia toxicity from topical benzocaine spray. J Am Geriatr Soc 1995;43:590.

7. Dinneen SF, Mohr DN, Fairbanks VF. Methemoglobinemia from topically applied anesthetic spray. Mayo Clin Proc 1994;69:886-8.

8. Brown CM, Levy SA, Susann PW. Methemoglobinemia: Life-threatening complication of endoscopy premedication. Am J Gastroenterol 1994;89:1108-9.

9. Rodriguez LF, Smolik LM, Zbehlik AJ. Benzocaine-induced methemoglobinemia: Report of a severe reaction and review of the literature. Ann Pharmacother 1994;28:643-9.

10. Bhutani A, Bhutani MS, Patel R. Methemoglobinemia in a patient undergoing gastrointestinal endoscopy. Ann Pharmacother 1992;26:1239-40.

11. Grum DF, Rice TW. Methemoglobinemia from topical benzocaine. Cleve Clin J Med 1990;57:357-9.

12. Collins JF. Methemoglobinemia as a complication of $20 \%$ benzocaine spray for endoscopy. Gastroenterology 1990;98:211-3.

13. Gupta PM, Lala DS, Arsura EL. Benzocaine-induced methemoglobinemia. South Med J 2000;93:83-6.

14. Eder HFC, McKee R. Congenital methemoglobinemia. A clinical and biochemical study of a case. J Clin Invest 1949;28:265.
15. Kern K, Langevin PB, Dunn BM. Methemoglobinemia after topical anesthesia with lidocaine and benzocaine for a difficult intubation. J Clin Anesth 2000;12:167-72.

16. Bunn H. Disorders of hemoglobin. In: Wilson JD, Braunwald E, Isselbacher KJ, et al, eds. Harrison's Principles of Internal Medicine, 12th edn. New York: McGraw Hill, 1991:1543-52.

17. Wright RO, Lewander WJ, Woolf AD. Methemoglobinemia: Etiology, pharmacology and clinical management. Ann Emerg Med 1999;34:646-56.

18. Balsamo P, Hardy WR, Scott EM. Hereditary methemoglobinemia due to diaphorase deficiency in Navajo Indians. J Pediatr 1964;65:928-31.

19. Scott EM, Hoskins DD. Hereditary methemoglobinemia in Alaskan Eskimos and Indians. Blood 1958;13:795-802.

20. Scott EM. The relation of diaphorase of human erythrocytes to inheritance of methemoglobinemia. J Clin Invest 1960;39:1176-9.

21. Ozsoylu S. Congenital methemoglobinemia due to hemoglobin M. Acta Haematol 1972;47:225-32.

22. Curry S. Methemoglobinemia. Ann Emerg Med 1982;11:214-21.

23. Griffin JP. Methaemoglobinemia. Adverse Drug React Toxicol Rev 1997;16:45-63.

24. Coleman MD, Coleman NA. Drug-induced methaemoglobinemia. Treatment issues. Drug Saf 1996;14:394-405.

25. Hjelt K, Lund JT, Scherling B, et al. Methaemoglobinaemia among neonates in a neonatal intensive care unit. Acta Paediatr 1995;84:365-70.

26. DeTorres JP, Strom JA, Jaber BL, Hendra KP. Hemodialysisassociated methemoglobinemia in acute renal failure. Am J Kidney Dis 2002;39:1307-9.

27. Clary B, Skaryak L, Tedder M, Hilton A, Botz G, Harpole D. Methemoglobinemia complicating topical anesthesia during bronchoscopic procedures. J Thorac Cardiovasc Surg 1997;114:293-5.

28. Guerriero SE. Methemoglobinemia caused by topical benzocaine. Pharmacotherapy 1997;17:1038-40.

29. O'Donohue WJ Jr, Moss LM, Angelillo VA. Acute methemoglobinemia induced by topical benzocaine and lidocaine. Arch Intern Med 1980;140:1508-9.

30. Rosse W, Bunn H. Hemolytic anemias and acute blood loss. In: Fauci AS, Braunwald E, Isselbacher KJ, et al, eds. Harrison's Principles of Internal Medicine, 14th edn. New York: McGraw-Hill Publishers 1998;CD Rom:Chapter 109.

31. Clifton J 2nd, Leikin JB. Methylene blue. Am J Ther 2003;10:289-91.

32. Cantor DS, Baldridge ET. Premedication with meperidine and diazepam for upper gastrointestinal endoscopy precludes the need for topical anesthesia. Gastrointest Endosc 1986;32:339-41.

33. Chuah SY, Crowson CP, Dronfield MW. Topical anaesthesia in upper gastrointestinal endoscopy. BMJ 1991;303:695. 


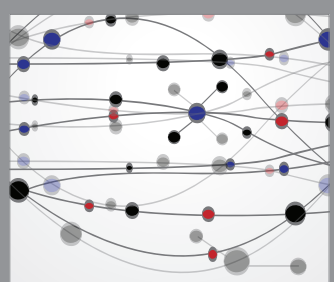

The Scientific World Journal
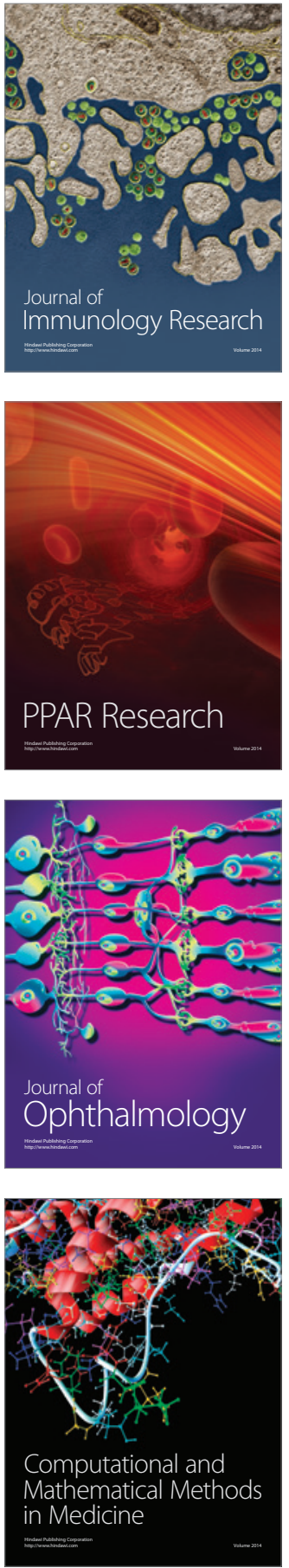

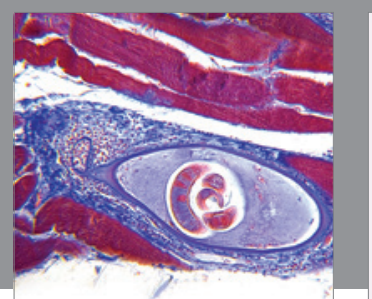

Gastroenterology Research and Practice

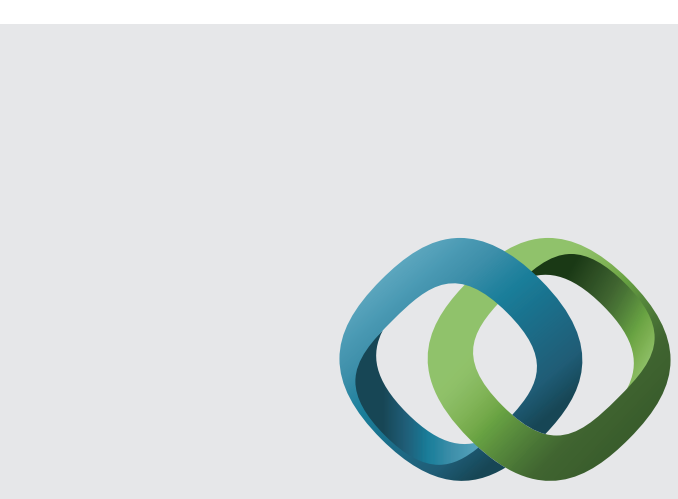

\section{Hindawi}

Submit your manuscripts at

http://www.hindawi.com
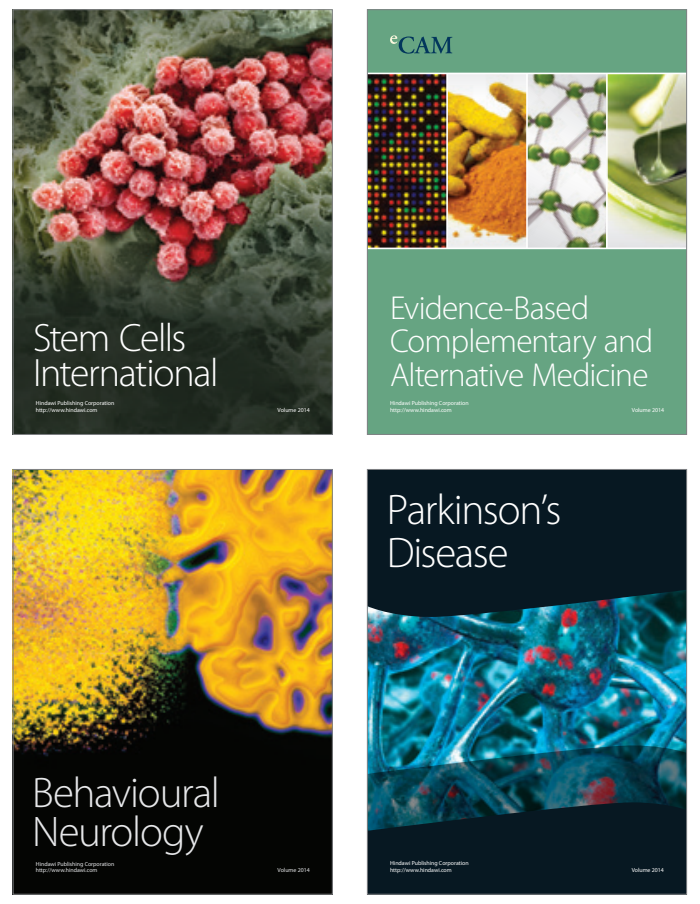
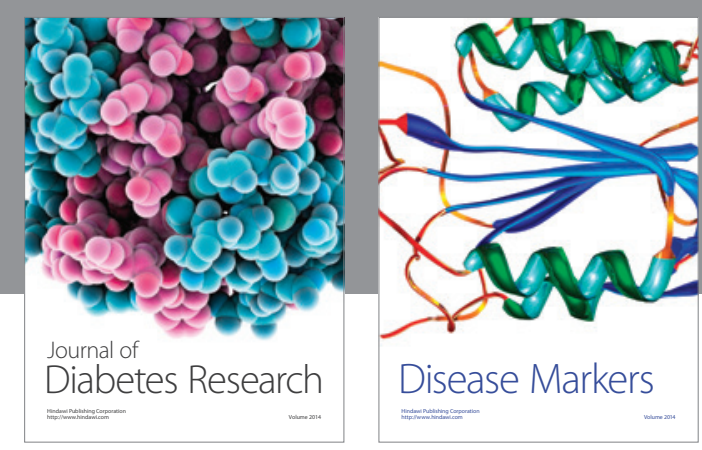

Disease Markers
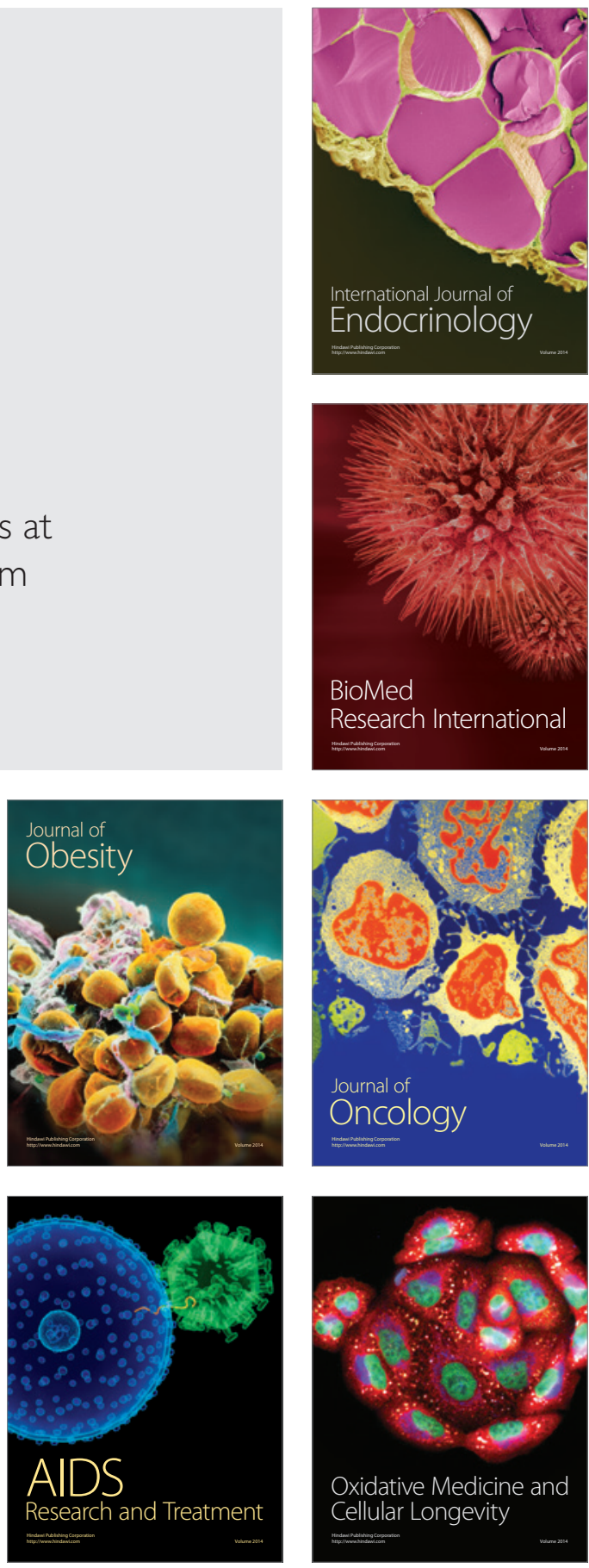